\title{
منهج الرسول صلي الله عليه وسلم في حماية المجتمع المسلم
}

جعفر خلف الله شبو

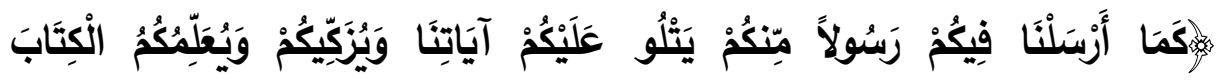

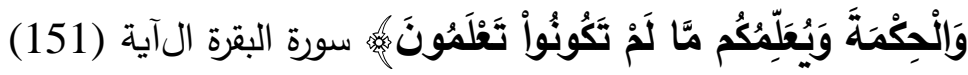
مستخلص البحث

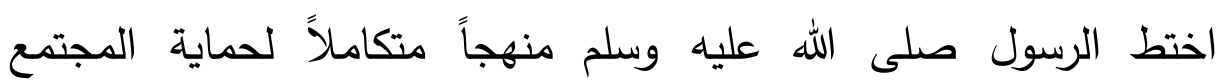

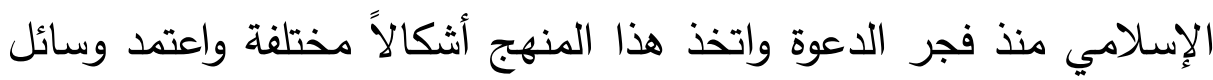
متنوعة لتحقيق غايته، ففي مكة عول الرسول صلى الله عليه وسلم على اللى

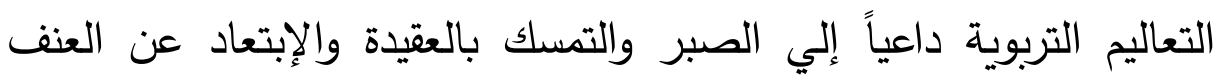

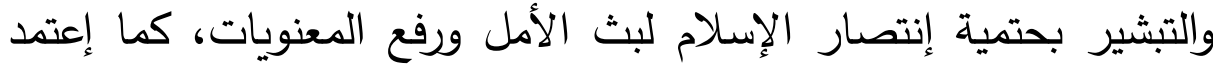


كتمان أخبار المؤمنين وتوجيه بعضهم للهجرة إلى حيث دأئل يأمنون.

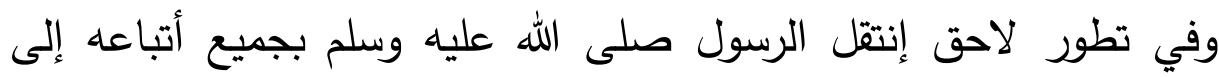

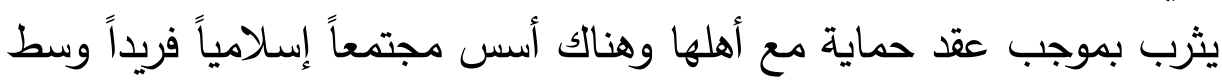

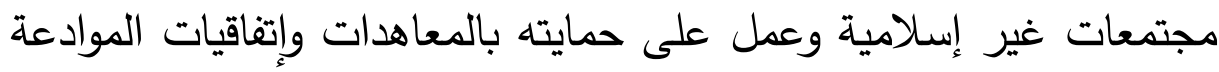

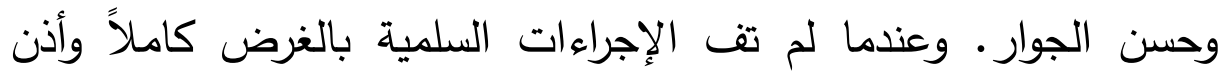
للمؤمنين بالقتال، تصدى الرسول صلى الله عليه وسلم للمعتدين عسكرياً، إلا أن الحرب التي خاضها كانت جميعها دفاعية ووقائية من أجل حماية

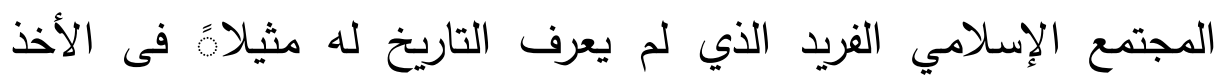
بصفات الكمال.

كلمات مفتاحية:- منهج، حماية، مجتمع.

جعفر خلف الله شبو، جامعة أم درمان الإسلامية - كلية التربية - قسم التاريخ والحضارة 


$$
\begin{aligned}
& \text { جعفر خلف الله شبو منهج الرسول صلي الله عليه وسلم }
\end{aligned}
$$

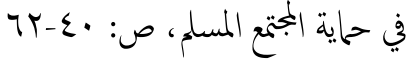

\section{Abstract}

The prophet of Islam, peace be upon him, has put and executed an integrated plan to defend the first Muslims and the Muslim society since the dawn of the Islam Call. The plan has taken different shapes and used several means to achieve its goal.

In Makah the plan relied on the educational doctrines and urged for patience and self control refraining from using force as there was no permission for fighting. The invocation of God and the prayers were carried out secretly. Some of the early believers were directed to emigrate to safe lands to escape persecution and oppression.

In later development and according to a protective treaty with the people of Yathrib, the prophet himself and all his companions emigrated to live there where the unique Islamic society was established. The means of protecting and defending it also developed considerably. Many treaties and safe -conducts to restore peace and stop aggressions and offensives were signed with the people of Yathrib and with the neighboring tribes. The prophet and his companions were forced to fight defensive and preventing wars to defend the Muslims' society: but they were never aggressive or oppressive ones.

Keywords:- Method, Protection, Society. 


\section{مقدمة}

لقد كان البحث في جوانب السيرة النبوية من أهم مناحي البحث في

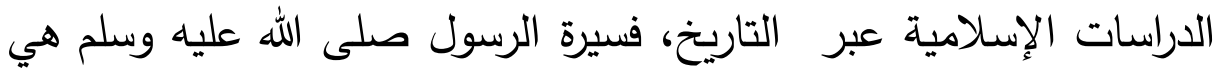
سنته العملية الهادية، وهي التطبيق الأمثل لكافة شرائع الإسلام وشعائره، ومن هنا تكتسب أي دراسة منهجية جادة للسيرة النبوية أهمية كبرى. أما إذا الإنا دعت حاجات العصر وثضاياه الملحة إلى تفحص ناحية معينة من سيرة النبي صلى الله عليه وسلم ودراستها من جديد فإن البحث حينئ يكتسب إلى أهمية زائدة لإستجابته لحاجيات العصر ودواعيه.

لقد طرأ خلال العقود الماضية ما دعا ويدعو إلى دراسة جوانب معينة من سيرة النبي صلى الله عليه وسلم و عرضها في مجلى علمي جديد من

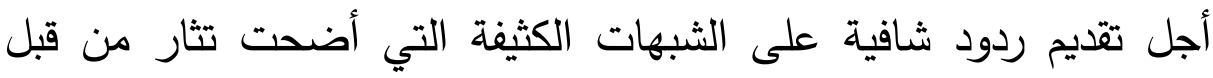
بعض الأوساط العلمية والإعلامية وأوساط الخصام الأيديولوجي المحتدم في عدائه للإسلام ولرسوله عليه السلام. ومن أكثر الثبهات التي ترددت والإعليه


الرسول صلى الله عليه وسلم وصحابته رضوان الله عليهم. وإنطلاقاً من توصيات الباحثين ومؤتمرات السيرة السابقة الداعية لسد ولهدات لهد الثغرات في مجال الدراسات المتخصصة فى هذا المجال تم إعداد هذا البحث بعنوان "منهج الرسول صلى الله عليه وسلم في حماية المجتمع المسلم "مفترضين أن حروبه صلى الله عليه وسلم لم تكن حروباً عدائية

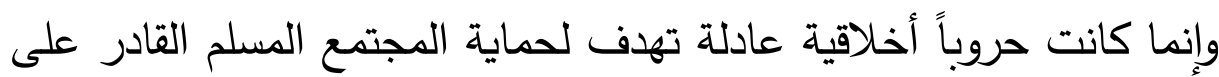
التعايش والتفاعل مع المجتمعات الأخري 


\section{الفصل الأول}

\section{التربية النبوية وحماية المجتمع المسلم}

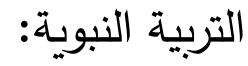

بدأ الرسول صلى الله عليه وسلم عمله في تأسيس وتتشئة الكيان الإسلامي بالتربية. فقد ذكر القرآن الكريم مهمة الرسول الأساسية بصراحة

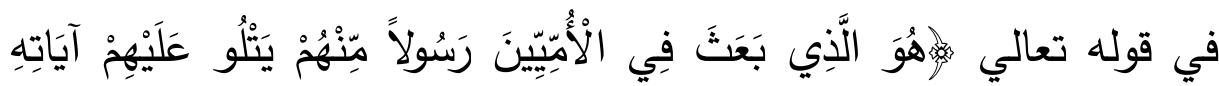

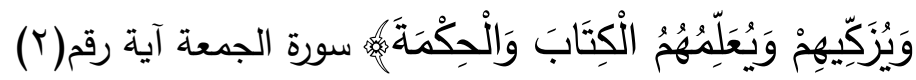
فقد حددت هذه الآية الكريمة من مهمات الرسول صلى الله عليه وسلم التعليم والتربية. وكان الجانب الأعظم في حياة الرسول صلى الله عليه وسلم هله

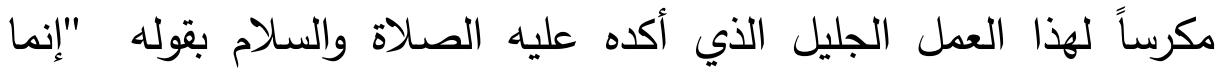
بعثت معلماً (2) "بالتعليم هو اللبنة الأولى من منهج الرسول صلى الله عليه

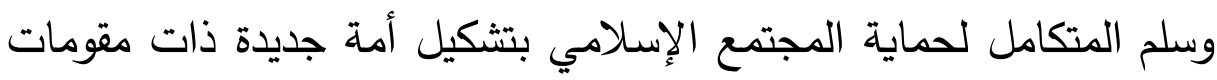

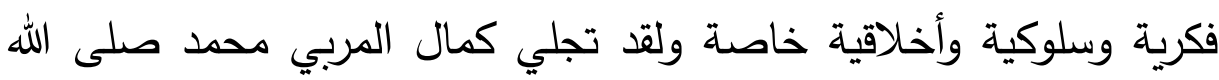

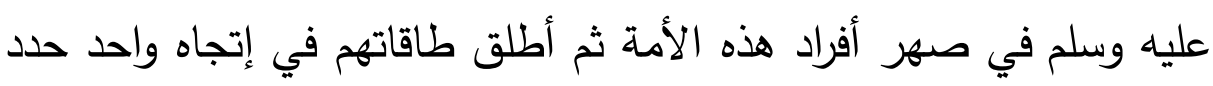

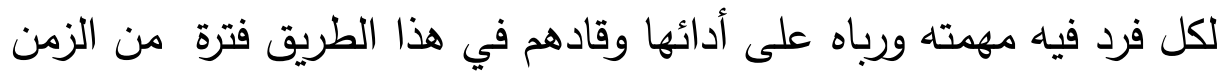

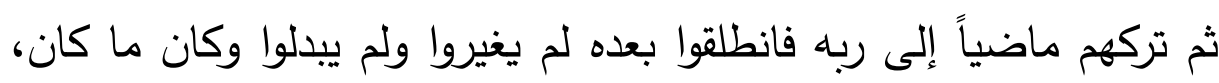

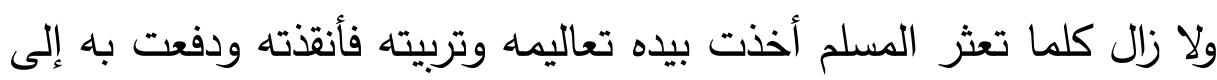
الأمام.

وظف الرسول صلى الله عليه وسلم منهجه التربوي لحماية الدعوة وضمان إستمراريتها وحماية أصحابه الذين هم نواة المجتمع المسلم ومادته. ولقد إتسم تطبيق المنهج النبوي تجاه العدو بالحكمة والديناميكية في كافة مراحله. فنجده في مكة يصبر ويأمر أتباعه بالصبر حتى لانئ ليخسر أتباعه 
قتلاً، وينشغل بقضايا الثأر عن تبليخ الدعوة، بينما تغيرت مواقفه في

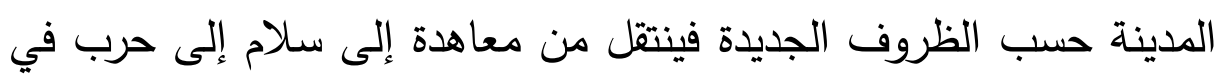
سبيل ما يحقق أمن المجتمع المسلم. نستعرض فيما يلي أمثلة من سيرته الثريفة ينجلي فيها حرصه صله صلى الله

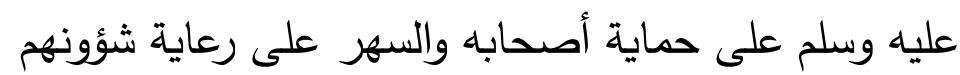
الإضطهاد والتعذيب :

تواترت الروايات على أن أذى قريش إثتد بالمسلمين بمكة في السنة

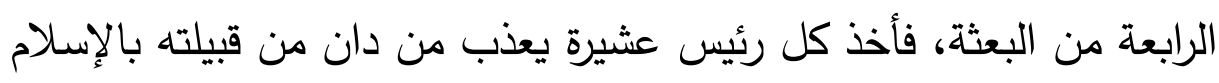

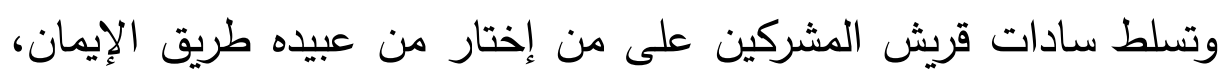

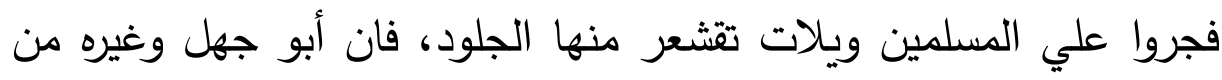
سادات قريش إذا سمعوا برجل له شرف ومنعة أنبوه وأخذوه وتوعدوه

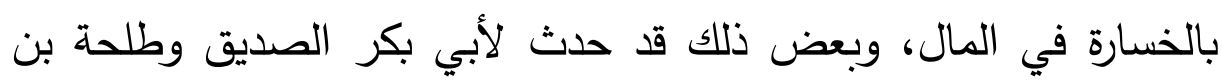

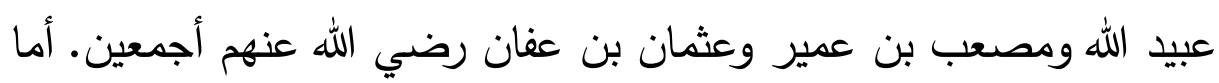
الضعفاء من العبيد والإماء فقد عذبوا عذاباً شديداً نذكر منهم بلالاً وصهيباً وآل ياسر وخباب بن الأرت وأبو فكيهه، ومن الإماء سمية بنت الخياط

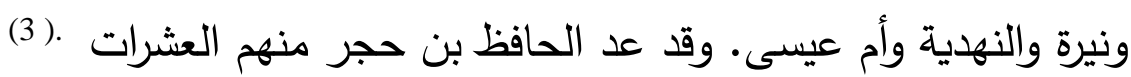

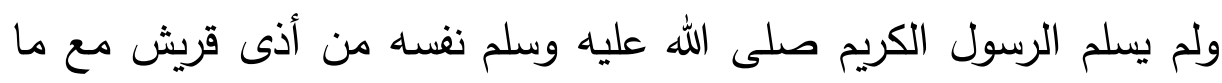
كان يتمتع باه من عزة ومنعة وشرف ومهابة فقد تعرض للإستهزاء

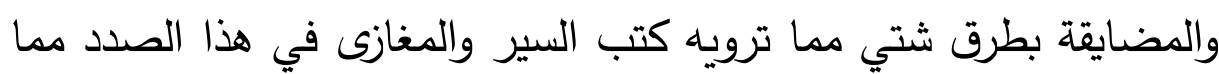
تعرض له من أبي جهل وأبى لهب والأخنث بن شريف وعقبة بن معند معيط

وغيرهم من المستهزئين . تدابير الحماية: 
إزاء هذا الموقف المتأزم إتخذ الرسول صلى الله عليه وسلم من التدابير ما يخفف وطأة الويلات والأهوال ويشد به العزائم ويحمي أتباعه.

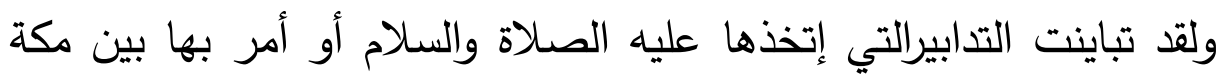
والددينة حيث إختلفت أوضاع المسلمين بين المدينتين المقدستين إختلافاً

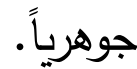

ففي مكة إختار الرسول صلى الله عليه وسلم دار الارقم بن أبي

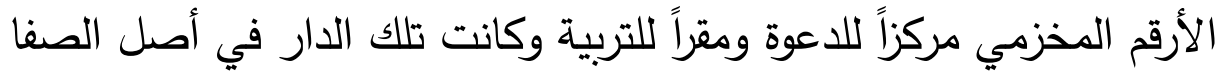
بعيدة عن أعين الطغاة ومجالسهم، فاختارها ليجتمع فيها المسلمون سراً

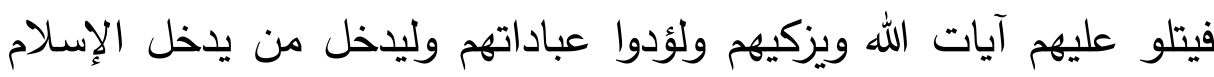

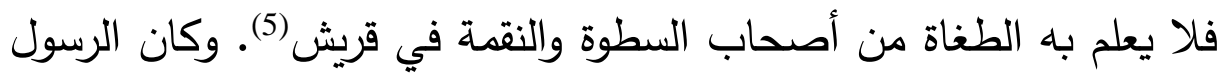

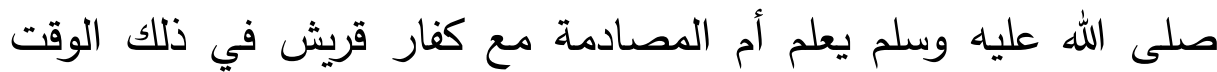
تؤدي إلى تدمير المسلمين وإبادتهم. وكان عامة الصحابة يخفون إسلامهه

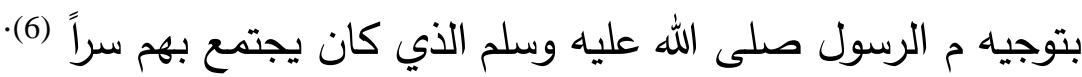
عندما إثتدت إعتداءات القرشيين على المسلمين بمكة في أوائل العام الخامس من البعثة بدأ التفكير الجدي في وسائل الخلاص من العذاب الأليم فنزلت سورة الزمر تثير إلى إتخاذ سبيل الهجرة، قال تعالي بولَّلَّلَذَّينَ

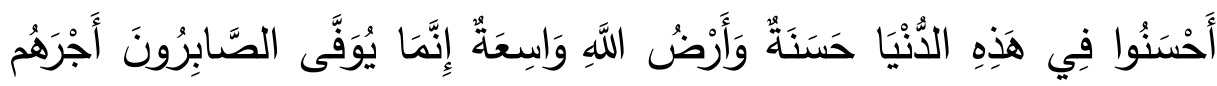

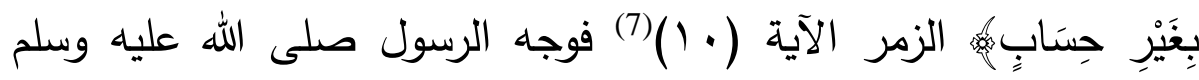
صحابته الكرام للهجرة للحبشة بعد أن علم أن ملكها النجاشي عادل النال لا يظلم


على رأسهم سيدنا عثمان بن عفان وزوجته رقية بنت رسول الله صلى الله عليه وسلم وتبع هذا الفوج آخر قوامه ثلاثة وثمانون رجلاً وثماني عشرة أو أو 
تسع عشرة إمراة وفشلت قري في إحباط هذه الهجرة لدقة الترتيات وللسرية

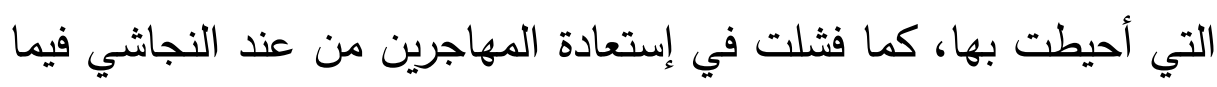

بعدا . (8)

ومن التدابير التي أقرها الرسول صلى الله عليه وسلم لحماية أصحابه

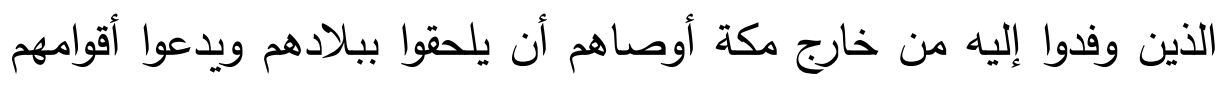

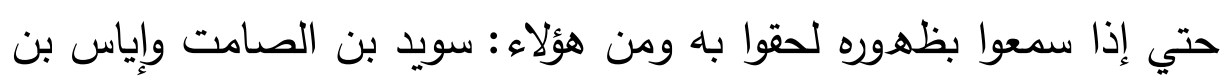

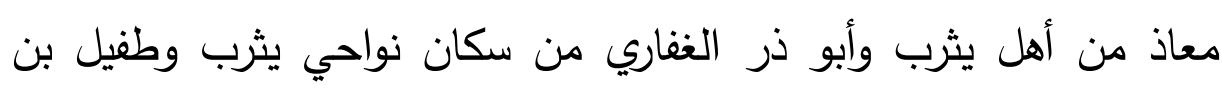

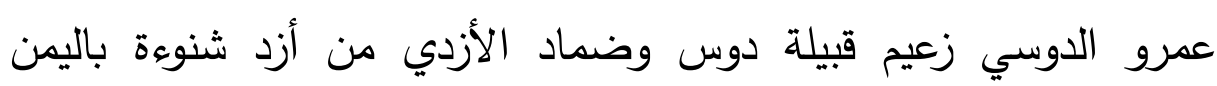

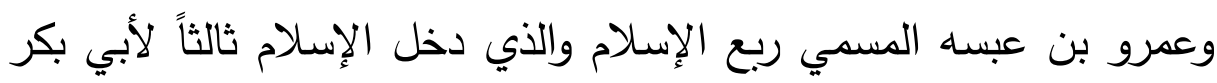
وبلال رضوان الله عليهم.

وفي موسم حج العام الحادي عشر من النبوة الموافق ليوليو عام

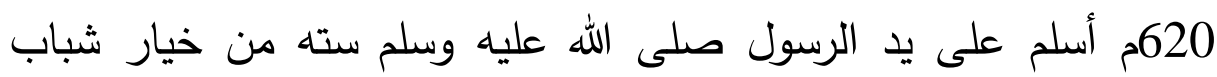

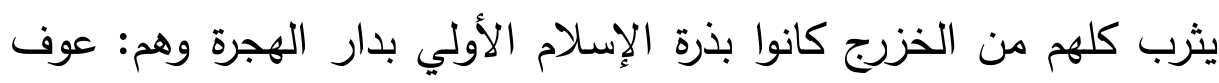

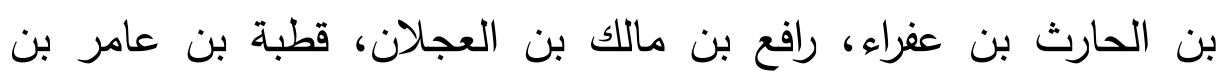

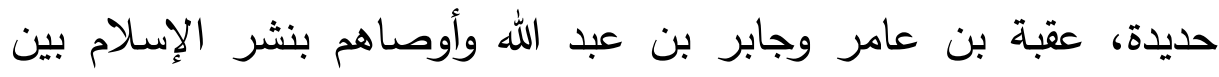

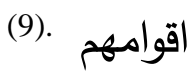

كان الرسول صلى الله عليه وسلم يوصي أصحابه في مكة بالصبر وضبط النفس ويقول لهم أنه لم يؤمر بقتال، ويبشرهم أن الله جاعل لهم اله

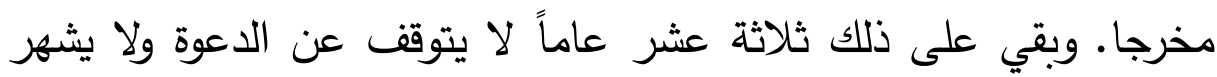

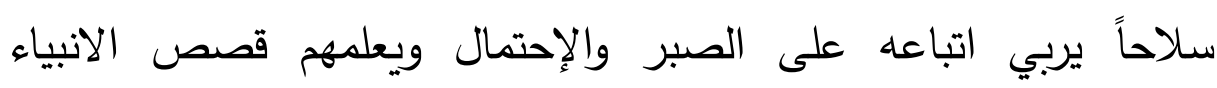
والمرسلين ليتأسوا بهم ومع ذلك يبشرهم بقرب النصر والفرج. 
بعد أن تمت بيعة العقبة الثانية ونجح الإسلام في تأسيس وطن له، وجه الرسول صلى الله عليه وسلم أصحابه للهجرة إلى يثرب الفراداً

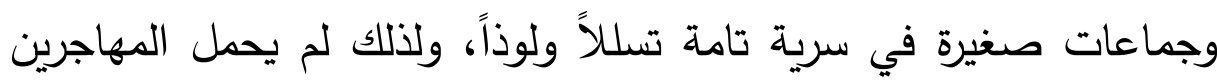
الأوائل أمتعة بل كانت الهجرة تعني إهدار المصالح والتضحية بالأهموال والنجاة بالدين فحسب، ومع ذلك أقدم عليها المسلمون بحماس شديد امتثالا

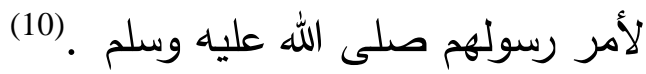
أما بعد الهجرة وظهور ملامح المجتمع المسلم فقد أتخذ منهج الرسول

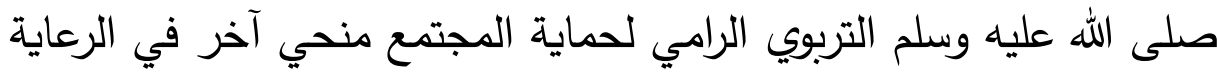
والعناية والسهر على شؤون الأتباع. فآخي بين المهاجرين والأنصار ليكفي التئي

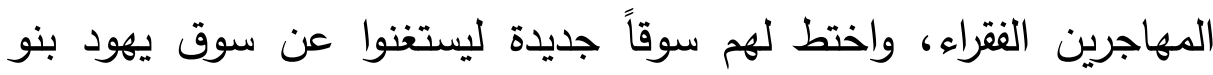

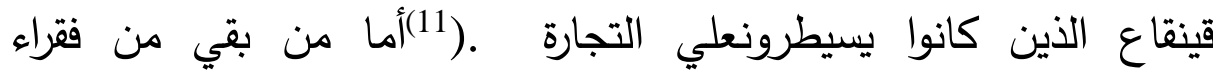

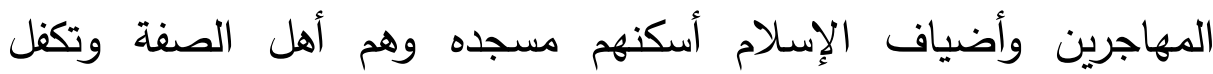
بطعامهم وشرابهم، والأحاديث في ذلك متواترة عن أبي هريرة رضي الله عند الهن

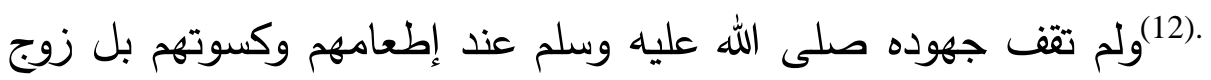

بعضهم كما في قصة زواج ربيعة الأسلمي وجليبيب (13). وفي المدينة المنورة توسع منهج الرسول صلى الله عليه وسلم التربوي لحماية المجتمع المسلم الوليد ليشمل جوانب عديدة من المثل العاليا والقيم التيم

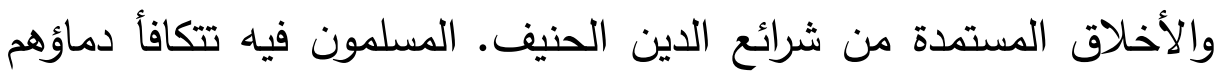
ويسعي بذمتهم أدناهم ولا فضل فيه لأحد على أحد إلا بالتقوى، تسودة شرعة الأمر بالمعروف والنهي عن المنكر التي تجعل من كل فرد فيه لأليه رقيباً علي كل شيءفيه، تسوده روح المحبة والإخاء والمسؤولية التي تجاوزت مزالق العصبية والقبلية وتجردت من هوى النفس وأسلمت قيادتها لله ولرسوله 
صلى الله عليه وسلم ومع كل ذلك نجد الرسول صلى الله عليه وسلم حاضراً

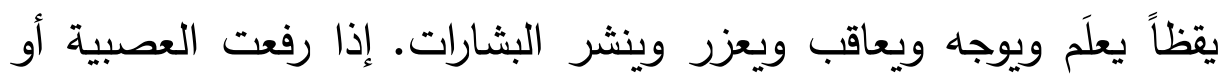

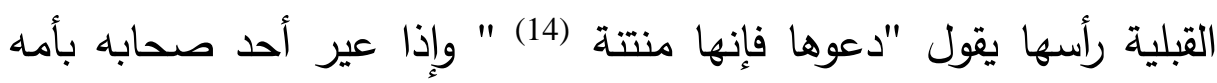
السوداء ينتصر له ويقول لمعيره "إنك امرؤ فيك جاهلية (15) " كما كان الإيمان هو الأساس المتين الي قام عليه أمن المجتمع المسلم علي يد ليد

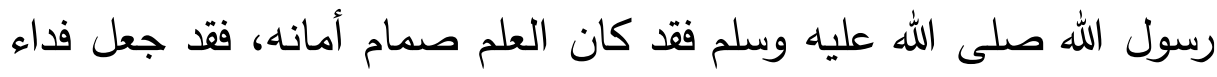
المتعلمين من أسرى بدر تعليم أبناء المسلمين في بادرة لم يسبق لها مثليل

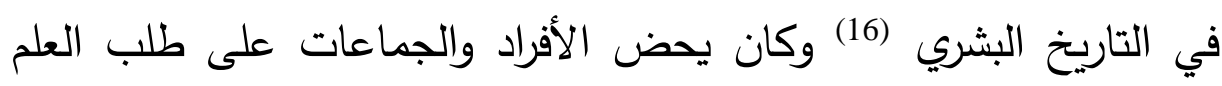

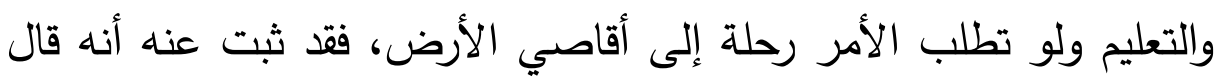

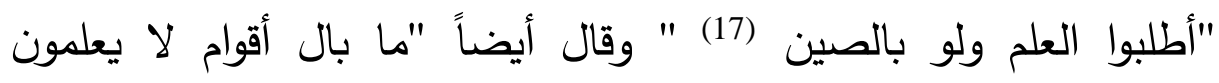
جيرانهم ولا يفقهونهم ولا يعظونهم ولا يأمرونهم ولا ينهونهم ؟ وما بال بال أقوام لا يعلمون من جيرانهم ولا يتفقهون ولا يتعظون ؟ والله ليعلمن قوم جيرانهم

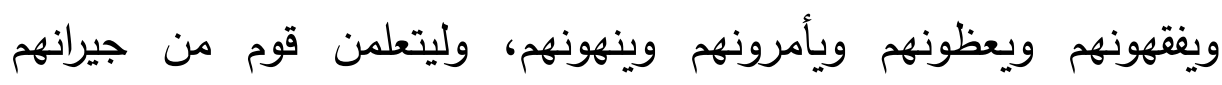
ويتفهون ويتعظون أو لأعاجلنه العقوبة وفي رواية أخرى أو لأعاجلنهم

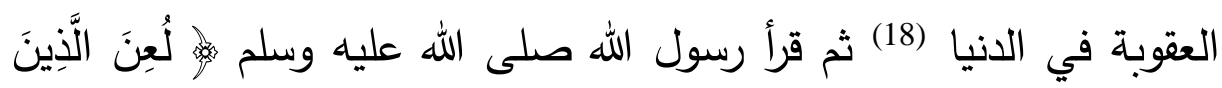

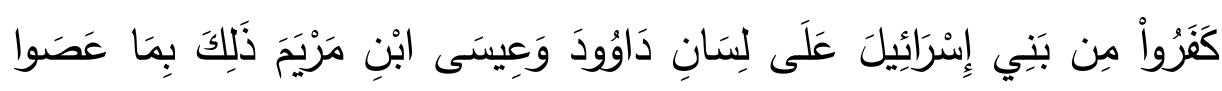

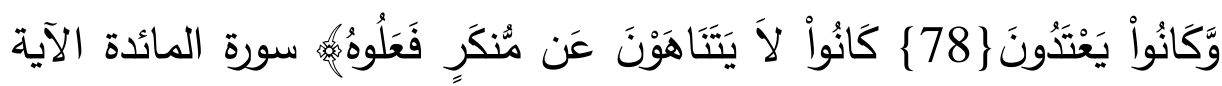
(19) $(\vee q-\vee \wedge)$

لقد كان منهج الرسول صلى الله عليه وسلم التربوي لحماية المجتمع المسلم نسقاً فريداً منسجماً مع الدعوة والرسالة بغرض على الهُ المتعلم أن يعلم وعلى الجاهل أن يتعلم وفي ذلك حماية وتحصين يتغلغل في اعماق

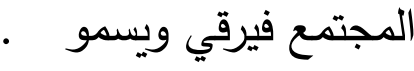


هوامش الفصل الأول : التربية النبوية

\section{الفصل الثاني}

إتفاقيات الصلح وعهود الأمان

إرتبط منهج الرسول صلى الله عليه وسلم في حماية مجتمعه المسلم

بالمدينة المنورة بالعمل على حقن الدماء ما وجد لذلك سبيلاً لإحكام

مباديء الدولة إحكاملاً يجعلها قادرة على الصمود والنمو على المدى البعيد وسنرى في الفصل كيف أن هذه الأهداف السامية كانت حاضرة في كافة الاتفاقات والمعاهدات والمواثيق والعصم التي أبرمها الرسول صلى الله عليه

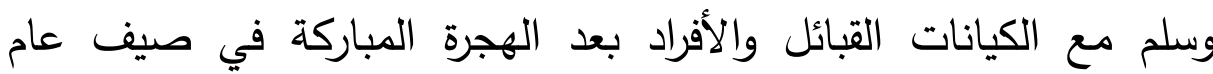
.022



ذكرنا في الفصل السابق أن ستة نغر من أهل يثرب أسلموا في موسم

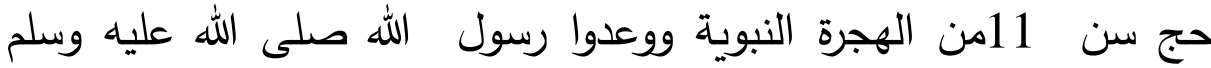
بإبلاغ رسالته إلى قومهم وكان من جراء ذلك أن جاء في الموسم التالي إثنا عشر رجلاً فيهم خمسة من الذين إلتقوا رسول الله صلى الله عليه وسلم في العام السابق والسبعة الآخرون من رؤساء العشائر بيثرب منهم: أبو الهيثم بن التيهان وعبادة بن الصامت ومعاذ بن الحارث )ابن عفراء (من بني

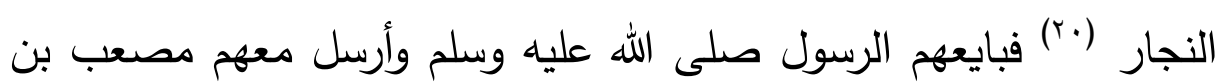
عمير العبدري ليعلم المسلمين شعائر الإسلام بيثرب. فصادف التهاد نهاح

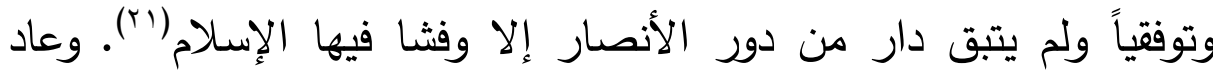


مصعب بن عمير رضي الله عنه قبل موسم حج العام الثالث عشر للبعثة يونيو 622م ليشر الرسول صلى الله عليه وسلم بالنجاح.

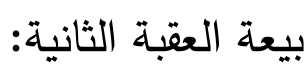

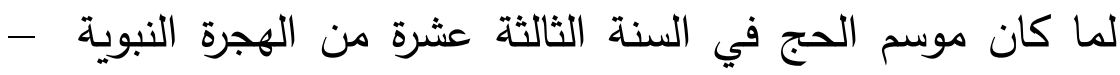

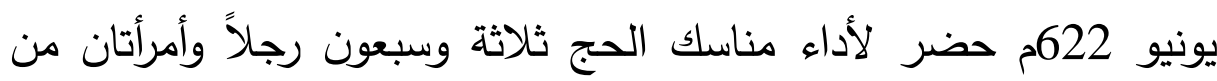
المسلمين من أهل يثرب للقاء الرسول صلى الله عليه وسلم، ولما قدموا مكة لهدئ جرت بينهم وبين النبي صلى الله عليه وسلم إتصالات سرية أدت إلى إتفاق الفريقين للإجتماع في أوسط أيام التشريق عند جمرة العقبة بمنى وأن يتم

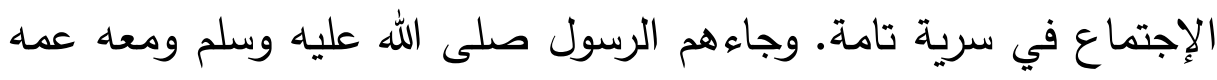
العباس بن عبد المطلب وهو يومئذ على دين قومه، جاء ليستوثق لإبن أخيه وتمت البيعة المعروفة في التاريخ الإسلامي ببيعة العقبة الثانية لللرسول صلى الله عليه وسلم على السمع والطاعة في المنشط والمكروه وعلى النفقة في العسر واليسر وعلى الأمر بالمعروف والنهي عن المنكر ولفئ وعلى أن تمنعوني مما تمنعون منه أنفسكم ولكم الجنة "(Yr).

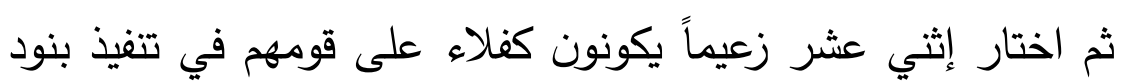

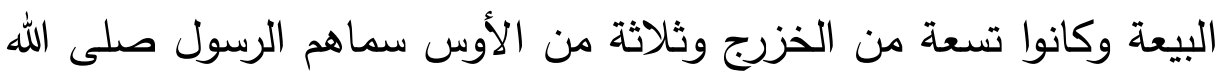
عليه وسلم النقباء (rr)، وقال لهم: " أنتم على قومكم بما فيهم كفلاء ككفالة

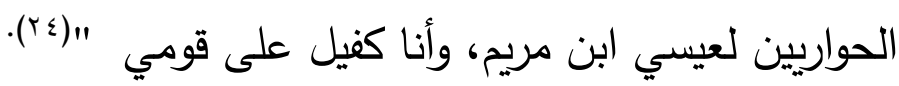
وضعت هذه البيعة المباركة الأساس المتين الذي قامت على عليه دئ دعائم

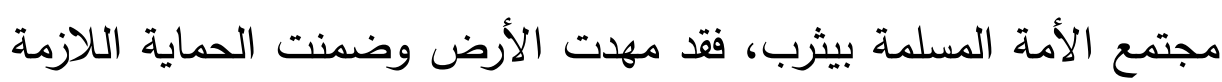

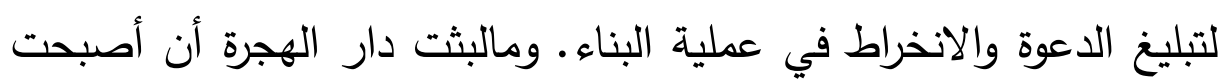
عاصمة لإمبراطورية مترامية الأطرف كان على الرسول صلى الخى الله عليه 
وسلم أن يتصدي لششاكل الهجرة بإيجاد صيغة ملائمة يتعايش فيها الناس

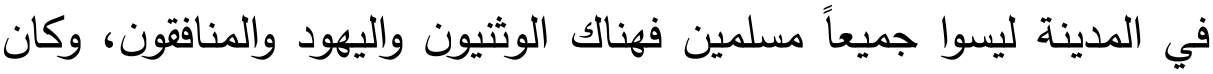
لابد من حل مشكلة المهاجرين الإقتصادية الذين تركوا أولادهم ومساكنهم

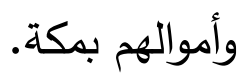

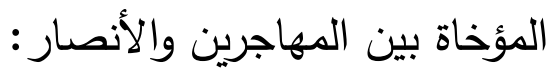
قال ابن القيم رحمه الله آخي الرسول صلى الله عليه وسلم بين

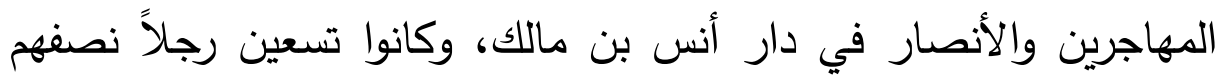
من المهاجرين ونصفهم من الأنصار آخي بينهم على المواساة ويتوارثون

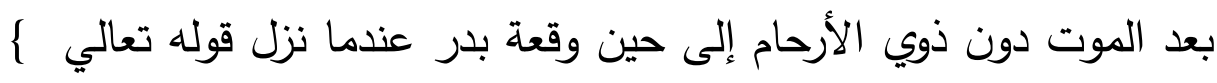
وأولوا الأرحام بعضهم أولى ببعض (10) فرد التوارث إلى الرحم دون عقد

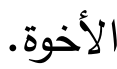

كان هذا الإخاء عملاً من أروع مآثر التاريخ: أذاب عصبية الجاهلية

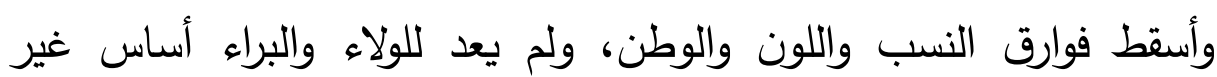

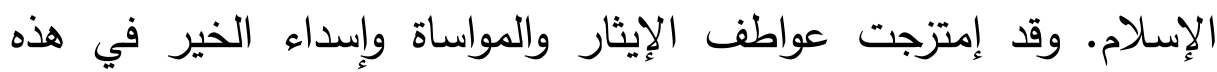
الأخوة وملأت المجتمع الجديد بأروع الأمثال وكانت حكمة فذألة وسياسة

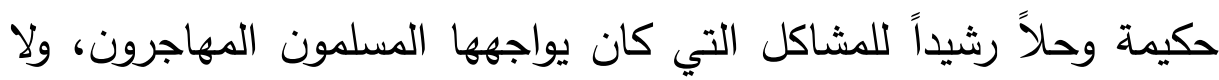
عجب فذلك منهج النبوة في رعاية المجتمع المسلم.

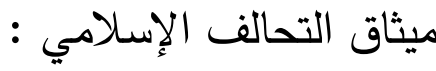
كما قام رسول الله صلى الله عليه وسلم بعقد المؤخاة بين المؤمنين،

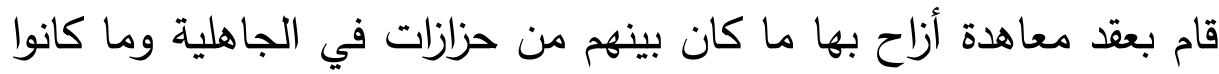
عليه من نزاعات قبلية جائرة، واستطاع بفضلها إيجاد وحدة إسلامية شاملة. ولقد وجد ما يستدعي إبرام ذلك الميثاق في ذلك الوقت، فقد كان مجتمع 
يثرب مؤلف من الأوس والخزرج وبينهم عداء قديم وليسوا جميعهم على ولى ولئ

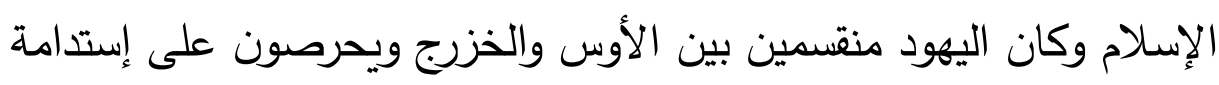
النزاع بينهما من أجل مصالحهم الإقتصادية.

كان من أمر رسول الله صلى الله عليه وسلم أن كتب أول وثيقة

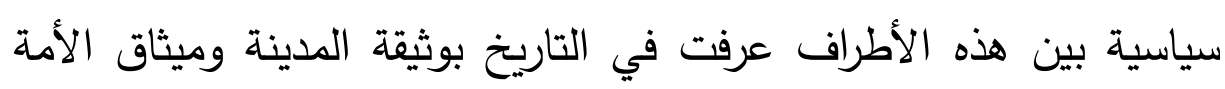

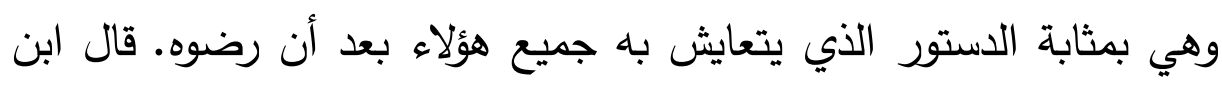
أسحق" :كتب رسول الله صلي الله علية وسلم كتاباً بين المهاجرين

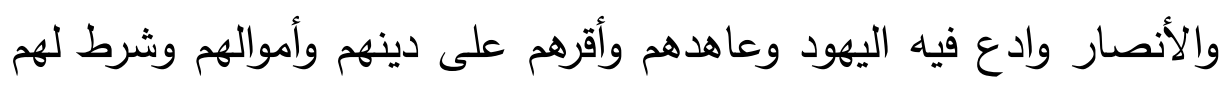

$$
\text { واشترط عليهم "(T). }
$$

أهم ما جاء في هذه الوثيقة التاريخية أنها جعلت المؤمنين والمسلمين من قريش ويثرب ومن تبعهم ولحق بهم وجاهد معهم أمة من دون الناس،

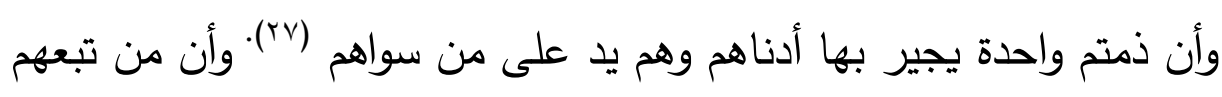

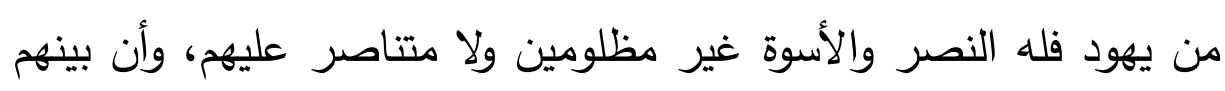

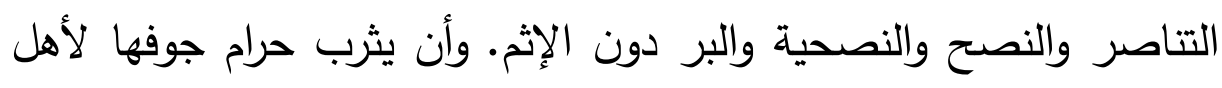
هذه الوثيقة وأنه مهما شجر من خلاف بين أهل هذه الصحيفة فمرده إلى دالى الرسول محدد صلي الله عليه وسلم (رد). بهذا التببير الحكيم أرسى رسول الله صلى الله عليه وسلم قواعد

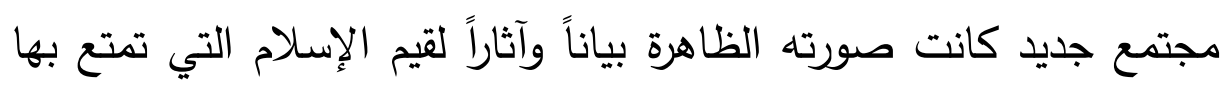
أصحاب الرسول صلى الله عليه وسلم وكان النبي صلى الله عليه وسلم ما لإنا ينفك يتعهدهم بالتعليم والتتربية وتزكية النفوس والحث على مالى مكارم الأخلاق، ويؤدبهم بآداب الود والإخاء والمجد والثشرف.

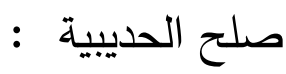


بعد الهجرة بستة أعوام تطورت الظروف في الجزيرة العربية لصالح المسلمين فسعي الرسول صلى الله عليه وسلم لإقرار حق السطلمين في أداء

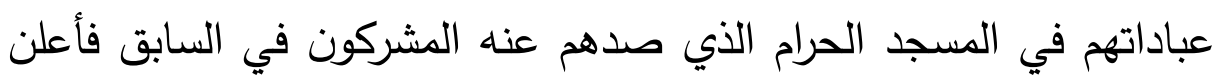

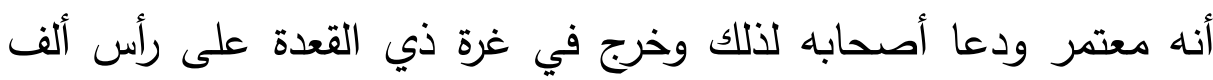
وأربعمائة من أصحابه بغير سلاح سوى السيوف في القرب.

تجلت رغبة الرسول صلى الله عليه وسلم في السلم وميله لحقن الدماء وحماية أصحابه بأوضح برهان في صلح الحسول الديبية فعندما حالت قريش بينه وبين ما اراد من العمرة وتعظيم بيت الله الحرام أبرم معها إتفاق صلح رآه

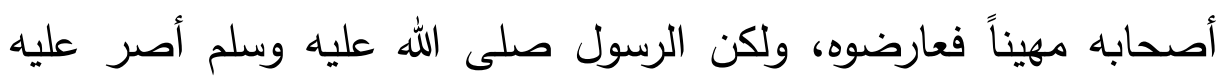
وأنفذه لأنه كان يعلم ما لا يعلمون (Y9).

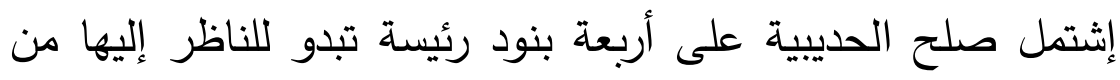

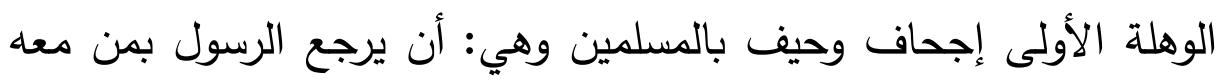

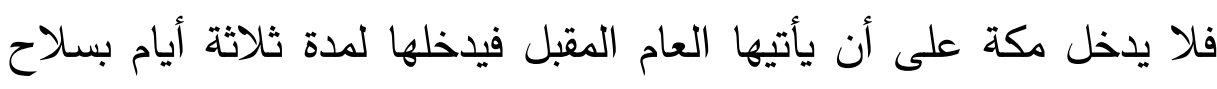

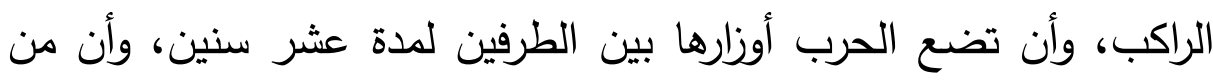

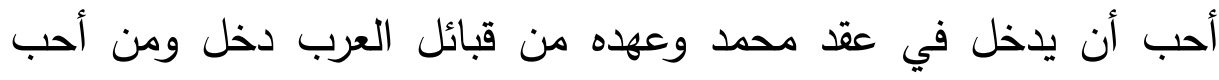
الدخول في عهد قريش دخل وتعتبر القبيلة التي تنضم إلى أي من الطرفين



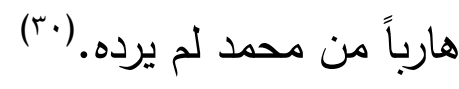

يقول ابن شهاب الزهري في صلح الحييبة: " ما فتح في الإسلام

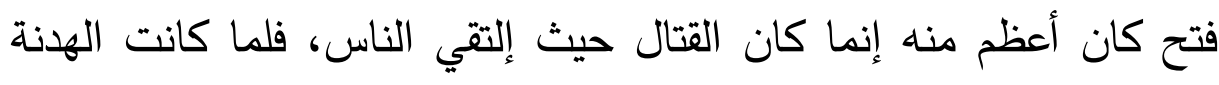
ووضعت الحرب أوزارها وأمن الناس بعضهم بعضاً فلم يكلم أحد بالإنسلام

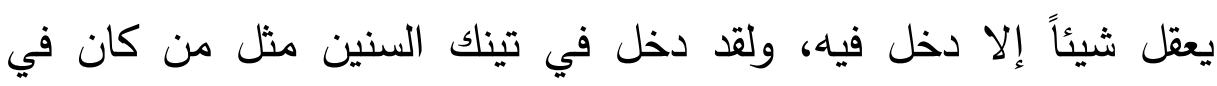


الإسلام قبل ذلك (") .والدليل من وقائع التاريخ على صحة قول الزهري أن الرسول صلى الله عليه وسلم خرج عام الفتح على رأس عشرة آلاف في قول قلى جابر بن عبد الله رضي الله عنه. ولقد أسلم كثير من زعماء قريش مثل مثل:

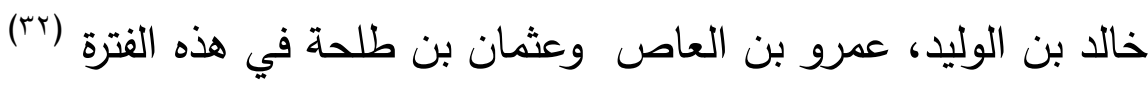
كا من آثار هذا الصلح المبارك أن تهذمت حجة قريش في في جمعها العرب على رسول الله صلى الله عليه وسلم يطوف بالكعبة ويعظمها ويكسوها. ومن آثاره كنلك أن فرغ الرسول من العرب الذين يسيرون في فلكان فلكي

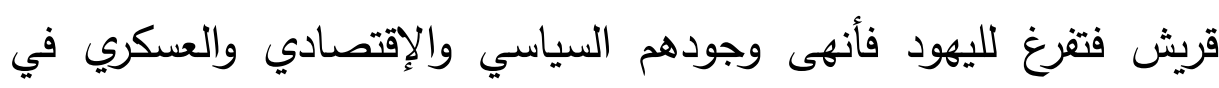

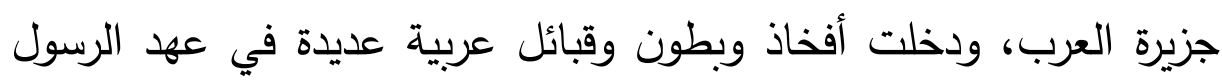
صلى الله عليه وسلم عندما إنقطع أملها بنصر أو عزة أو بغير الإنسلام

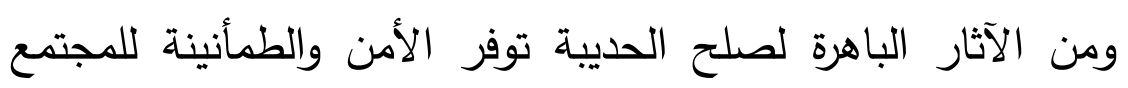

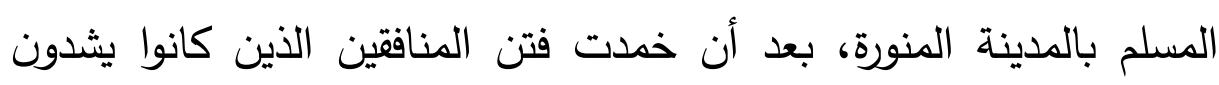

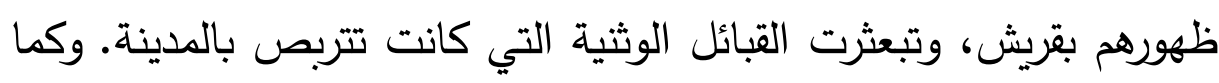

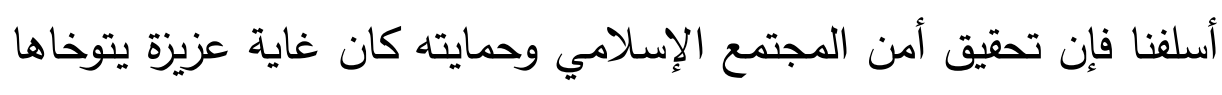

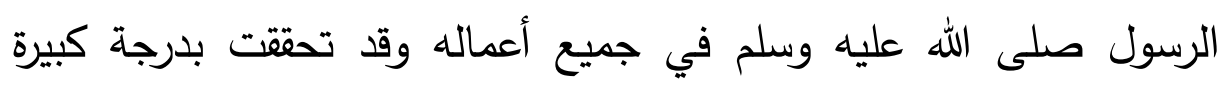

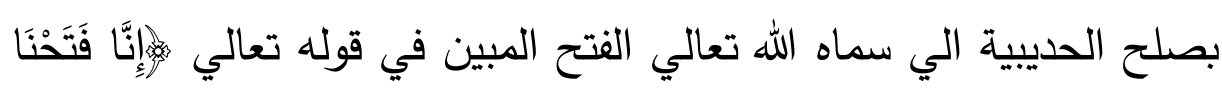

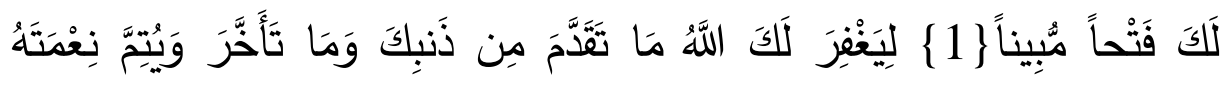

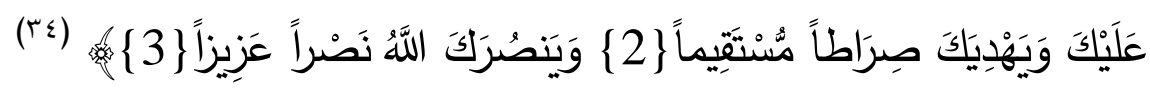
موادعة القبائل: ظل الرسول صلى الله عليه وسلم حريصاً دائماً أن لا يشغله أمر

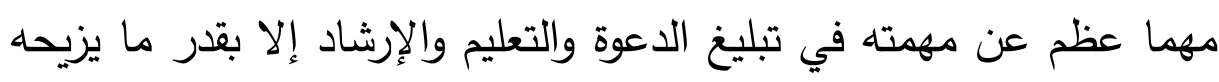


عن طريقه. وكان مدركاً إدراكاً راسخاً أن أمثل السبل لذلك هو تحقيق أكبر قدر من السلام. وقد جعل إعتراض عير قريش هدفاً إستراتيجياً له لإنسترداد

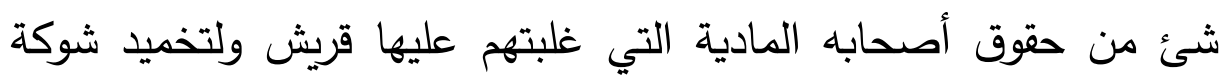

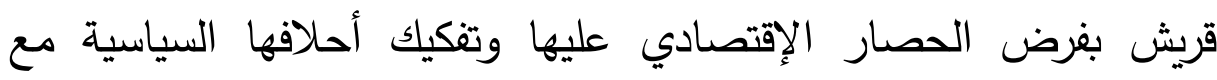

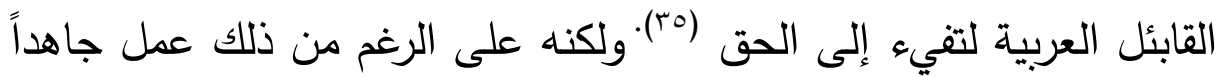
على حقن دماء أصحابه ودماء أعدائه القرشيين ما وجد إلى ذلك الك سبيلاً.

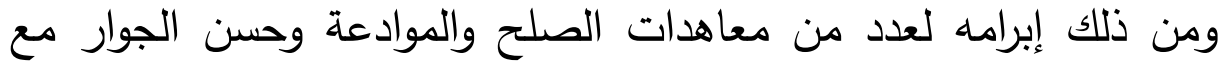
بعض القبائل الدقيمة حول الدينة على الطريق التجاري للشام. ففي أول خروج حربي له في صفر من العام الثاني للهجرة سار إلى ودان، وهو واد الثياد

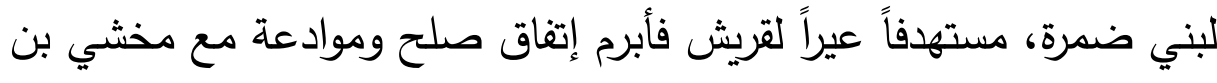
عمرو زعيم بني ضمرة تعهد لهم فيه بتأمينهم على تتفسهم وأموالهم والنصر عللا من رامهم بسوء على أن لا يحاربوه في دين الله ولا يناصروا عليه عدواً

وقد أبرم رسول الله صلى الله عليه وسلم معاهدتين مماتلتين مع بني

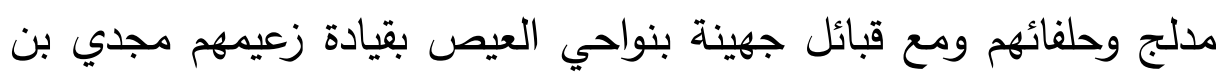
عمرو الجهني. .ولقد تمكن مجدي بالفعل من التوسط بين المسلمين والقرشيين في سرية سيدنا حمزة عندما إعترض عيراً بقيادة أبي جهل قريباً من ساحل البحر بناحية العيص (rv).

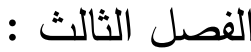




نتتاول في هذا الفصل بالإستعراض والتحليل أسباب ونتائج الحروب المتعددة التي خاضها الرسول صلى الله عليه وسلم ضد أعدائه من

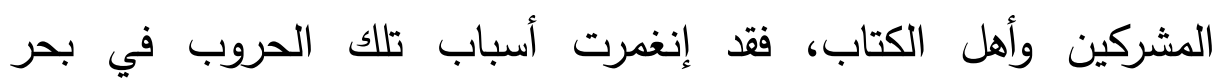
التفضيلات المتكاثرة التي ساقها كتاب السير والمغازي، وربما إثتبه الأمر على البعض فظنوا أن تلك الحروب لم يكن لها من مبرر سوى العدوان

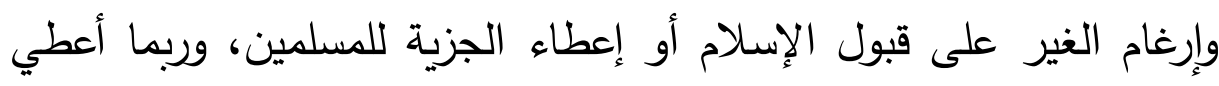

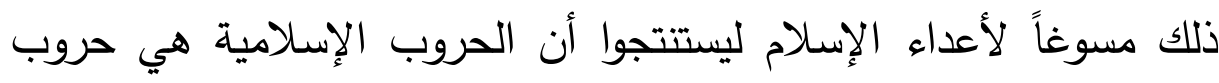
غصب ونهب وأن دوافعها إقتصادية أكثر مما هي دينية وأخلاقية في إطار الإنال منهج الرسول صلى الله عليه وسلم لتبليغ الدعوة وحماية المجتمع المسلم. غزوات النبي صلي الله عليه وسلم : لقد حارب رسول الله صلى الله عليه وسلم سبعاً وعشرين غزوة هي:

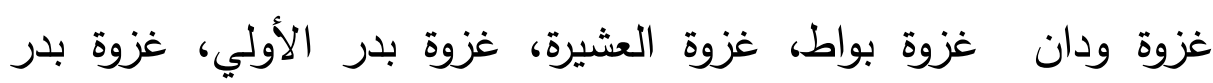

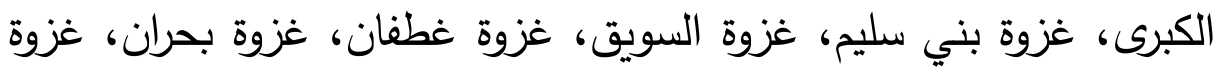

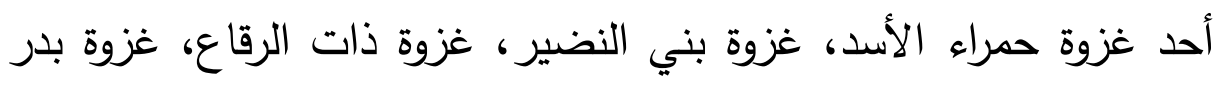

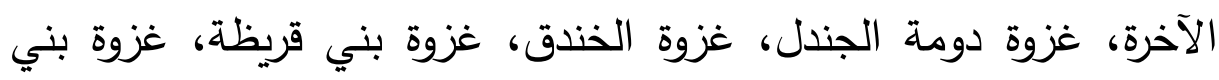

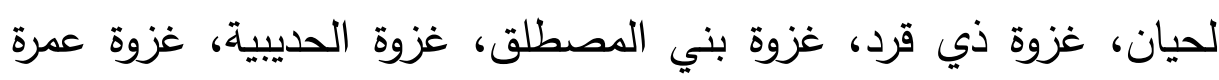

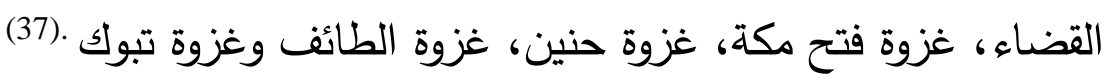
أما الغزوات التي وقع فيها قتال فعلي بين النبي صلى غلى الله عليه



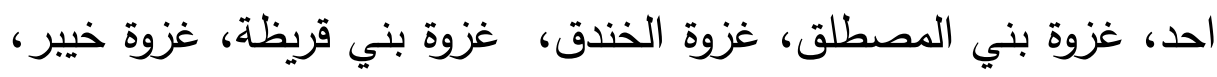

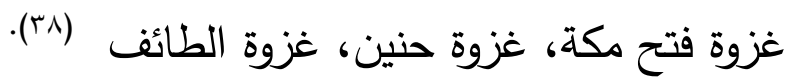

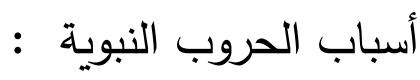


بالإستعراض التحليلي لوقائع غزوات الرسول صلى الله عليه وسلم

وسراياه نجد أن هناك أربعة أسباب رئيسة حملت الرسول صلى الله عليه


البيضة ورد الأعداء، المعاقبة على نقض العهود والتأليب على المسلمين

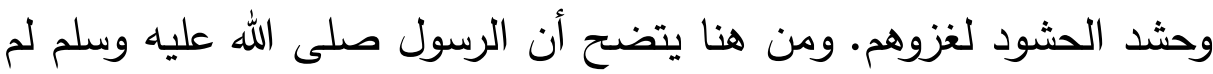

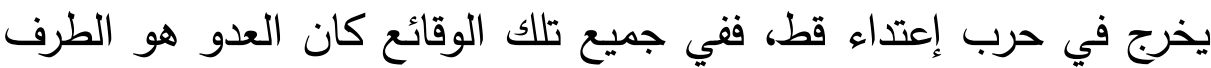

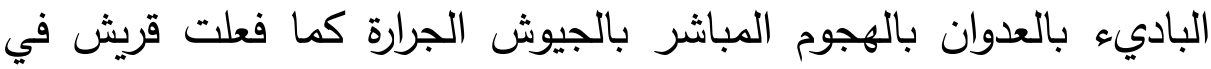
بدر وأحد والخندق (ra) ولم يطلب الرسول صلى الله عليه وسلم القبائل المتحالفة مع قريش إلا بعد أن طلبته وبدأته بالعدوان إما بقتل أصحابه أو أو الصات بالإعتداء على مقدرات المجتمع المسلم كفعل هذيل وبني لحيان وعضل


كما حارب الرسول صلى الله عليه وسلم من بدأه بالعدوان وتصدى فئ

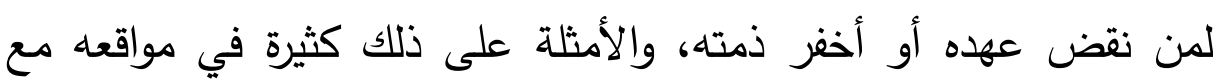


المؤامرات والعمل على إستئصال شأفة الإسلام فقد نبخ فيله كفار قريش وقبائل غطفان وهوازن وبني فزارة إلى جانب اليهود (؟r). أما الذين شرعوا في التجهيز لحربه وأحبط محاولاتهم فهم جبهة



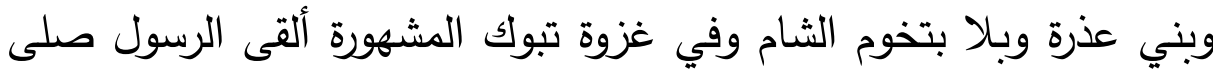
الله عليه وسلم الرعب في قلوب جموع بني الأصفر الذين نصبوا لحربه

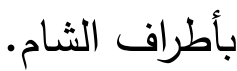


كانت السرايا التي بعثها رسول الله صلى الله عليه وسلم إلي الأعداء من حوله لردع وإجهاض الدحاولات الدتكرة للإعتداء على الرسول

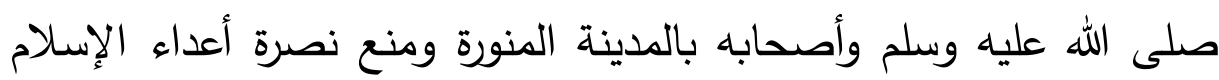

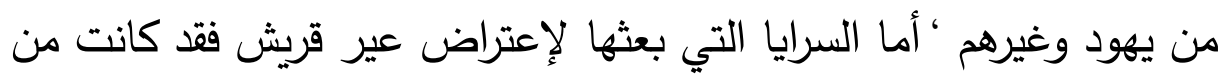

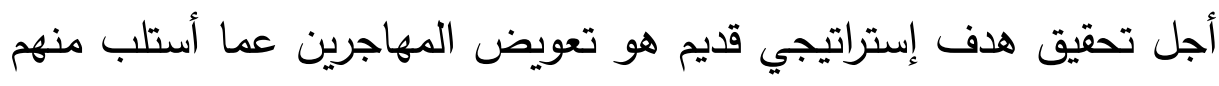
بمكة وإضعاف إقتصاديات قريش وتوهينها مما تقدم نخلص إلى إنتقاء نظرية الحرب العدوانية الدنافية للقيم والأخلاق عن حروب النبي صلى الله عليه وسلم فهو لم يسع قط للحرب التبال من أجل التوسع الإقليمي أو نهب ثروات الشعوب أو تحقيق مكاسب ذاتية،

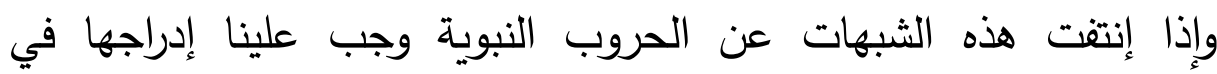
مصاف الحروب الأخلاقية العادلة. 




ا. . صحيح البخاري "كتاب العلم 1/216 "وصحيح مسلم في باب

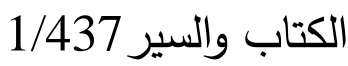

r. ابن حجر ، أحمد مبن علي بن محمد، الإصابة في تمييز الصحابة )

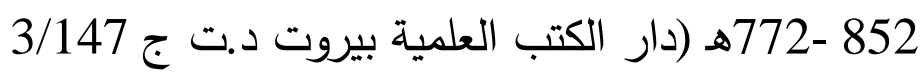
r. ابن هشام، محمد بن عبد الملك، السيرة النبوية، تحقيق مصطفي السقا وابراهيم الأبياري و عبد الحفيظ شلبي، د .ت دار إحياء التراث العربي $4 / 256$

ع. عماد الدين خليل، دراسة السيرة، مؤسسة الرسالة، بيروت 1401 0. ابن هشام، السيرة النبوية 1/364 ד. ابن القيم، زاد المعاد، المطبعة المصرية 1347هـ 1/23 V. سهيلي عبد الرحمن بن عبد الله، الروض الأنف في تفسير السيرة النبوية، دار المعرفة، بيروت 3/217 1398

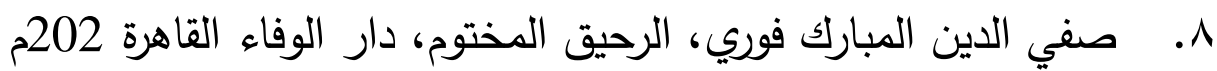
ص ص 148

9. ابن هشام، السيرة النبوية 442 -1/441

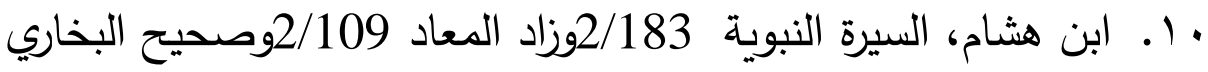
2/584

11 rا ـ ـحيح البخاري 1/402وصحيح مسلم 2/258 1/ 1/421 - 422 - ابن هشام، السيرة النبوية 
ـ ا ـ سعيد حوى، الرسول صلي الله عليه وسلم، دار الكتب العربية، بيروت 2/207 1978

10 ـ صحيح البخاري، كتاب طلب العلم 1/345 1/210 17 ـ ابن القيم، زاد المعاد 2/139وفتح الباري 7/493

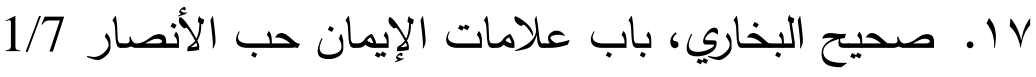

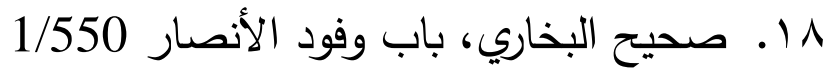
19 ـ ابن هشام، السيرة النبوية، مصدر سابق 1/438

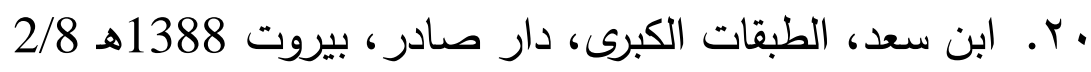

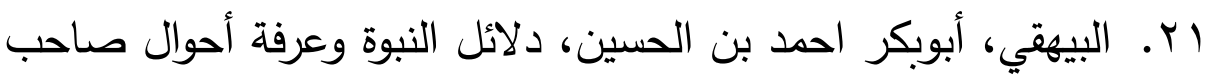

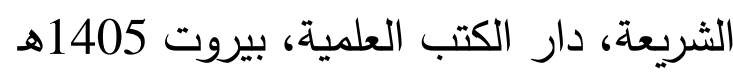
4 Y T/159 ابن هثام، السيرة النبوية rr. صحيح البخاري 698 - 2/696وابن هشام 307 - 2/297

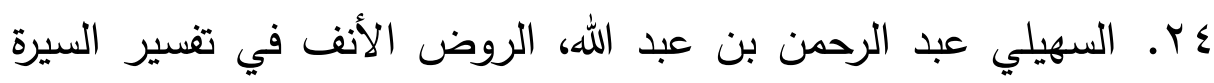
النبوية، دار المعرفة، بيروت 1398هـ

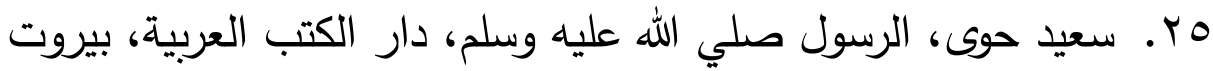
1/177 1978

צr. ابن سعد، الطبقات الكبرى ، مرجع سابق 2/129 1/YV

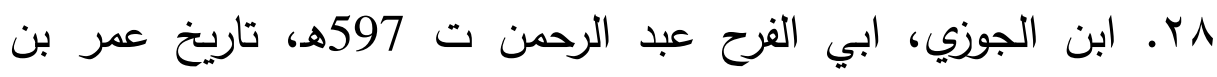
الخطاب، مطبعة التوفيق مصر 1379هـ ص ص 40- 39 وץ. البيهقي، ابوبكر احمد بن الحسين، دلائل النبوة ومعرفة أحوال

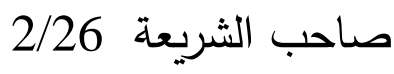


• r. الطبري، ابن جرير، تاريخ الأمم والملوك، دار الكتب العلمية، بيروت 2/160هـ 1408

اس. ابن هشام، السيرة النبوية 2/389وصحيح البخاري، باب الغزوات 2/612- 622

rس. الواقدي، محمد بن عمر، كتاب المغازي، تحقيق مارسدن جونز،

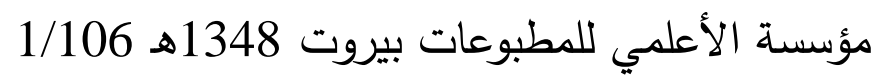
2/317 كس. ابن هشام، السيرة النبوية، ع ז. صحيح مسلم، باب غزوات الرسول صلي الله عليه وسلم 2/615 هr. ابن سعد، الطبقات الكبرى 2/14

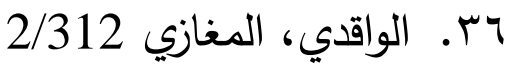

אY rV

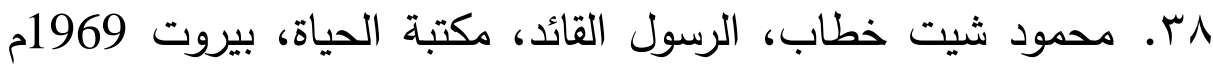
ص ص 171 9 ب. ابن هشام، السيرة البنوية 4/411

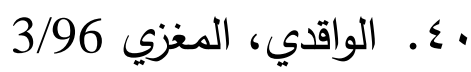
اءـ ـ محمود شيت خطاب، الرسول القائد ص ص 211



